\section{Sanja Cvetnić}

Filozofski fakultet Sveučilišta u Zagrebu,

Odsjek za povijest umjetnosti

Izvorni znanstveni rad / Original scientific paper

UDK / UDC: 728.82-035.3(497.5 Vukovina)

6. 7. 2013.

\title{
Pavao Kamenar i drveni dvorac u Vukovini
}

Ključne riječi: Pavao Kamenar, 19. stoljeće, drveni dvorac, Vukovina, Alapići, Turopolje Key words: Pavao Kamenar, 19th century, timber manor house, Vukovina, Alapy, Turopolje

Od malobrojnih sačuvanih drvenih dvoraca na području Turopolja, posebno mjesto zauzima drveni dvorac u Vukovini. Drugi drveni dvorci građeni su u 19. stoljeću, poput onoga obitelji Modić-Bedeković u Donjoj Lomnici (1806.) ili stare župne kurije u Starom Čiču (1831.), ili su pak poput one Jelačićeve u Kurilovcu propali u novije vrijeme. Samo je Josipovićev dvorac (također u Kurilovcu) »preventivno razgraden «. Uz novi podatak o vlasniku dvorca u Vukovini u desetljeću prije katastarskoga popisa 1861. godine, Pavlu Kamenaru, čije inicijale čitamo na portalu dvorca i koji je svoje knjige označavao naljepnicom (ex libris) s natpisom: "Iz Knjižnice PAVLA KAMENARA Vukovinskog.", prilog daje kratak pregled literature i arhivskih podataka o vlasnicima nakon razdiobe vukovinskog vlastelinstva početkom 17. stoljeća i njegove predaje na korištenje redovnicama samostana klarisa u Zagrebu sredinom 17. stoljeća. Namjera članka je također upozoriti na drveni dvorac koji je trenutačno u kritičnom stanju, a sve u nadi da će taj jedinstveni dvorac iz 18. stoljeća (i uz Škarićevo u Hrvatskom zagorju, u Hrvatskoj uopće) dočekati obnovu.

O drvenom dvorcu (sl. 1), ${ }^{1}$ poznatom kao »kurija Alapić« u Vukovini u Turopolju, u povijesnoumjetničkoj literaturi nalazimo nekoliko spomena. Anđela Horvat (1982.) osvrnula se na njega dvjema rečenicama: »Kao kakva oronula ljepotica stoji u turopoljskoj Vukovini jednokatna kurija Alapić s tornjićem na strmom krovištu zgrade pačetvorinastog tlocrta. Široka vrata još imaju rokoko okove. $\aleph^{2}$

Jednokrilni i jednokatni drveni dvorac pravokutnoga tlocrta podignut je na temeljima od cigle i zaključen strmim četverostrešnim krovom pokrivenim biber-crijepom. To nije izvorni pokrov jer je sačuvan preventivno skinuti dio krovišta (1997.) - krovni istak - pokriven šindrom. Dvorac je ožbukan i to tako da su na drvene planjke zabijene letvice a potom je nanesena žbuka. Žbuka je popucala i dijelom otpala, pa je ispod vidljiva građa. Glavno je pročelje okrenuto prema jugoistoku. Prizemlje je od kata odijeljeno razdjelnim vijencem. Njegovu trodijelnu podjelu naglašavaju istaknuti pilastri koji su posljedica drvene konstrukcije, to jest istaka drvenih planjki »obučenih« u žbuku. Artikulacija pročelja jasno otkriva reprezentativno stambeno značenje kata te posebno središnje dvorane. Naime, od četiri pročelna prozora na katu, središnja dva su iznad ulaznih vrata i tvore jednu naglašenu široku os, a simetrično joj se sa svake strane nalazi po jedna uža prozorska os, što odgovara trima reprezentativnim prostorijama kata. Bočna pročelja imaju po dvije prozorske osi, a na katu začelja simetrično su postavljena dva veća i jedan manji prozor. Sa začelja su prigrađena dva zahoda. Pod prizemlja niži je od sadašnje razine terena, što s pročelne strane nije vidljivo. Od ulaza se lijevo silazi u još niži podrum, nasuprot ulaza je zidana kuhinja i stubište postavljeno uz začelnu stranu, a desno je prostor namijenjen domaćinstvu. Iz prizemlja se na prvi kat uzlazi dvokrakim stubištem s izvornom drvenom balustradom. Ono vodi iz ulaznoga prostora u predvorje salona, dviju reprezentativnih soba na katu te dviju manjih $\mathrm{u}$ sjeverozapadnom $\mathrm{i}$ jugozapadnom uglu. $U$ prostorije na katu može se ući iz predvorja, ali ih povezuje i enfilade. Njihov raspored, veličina i elegantni razmjeri iznenađuju 


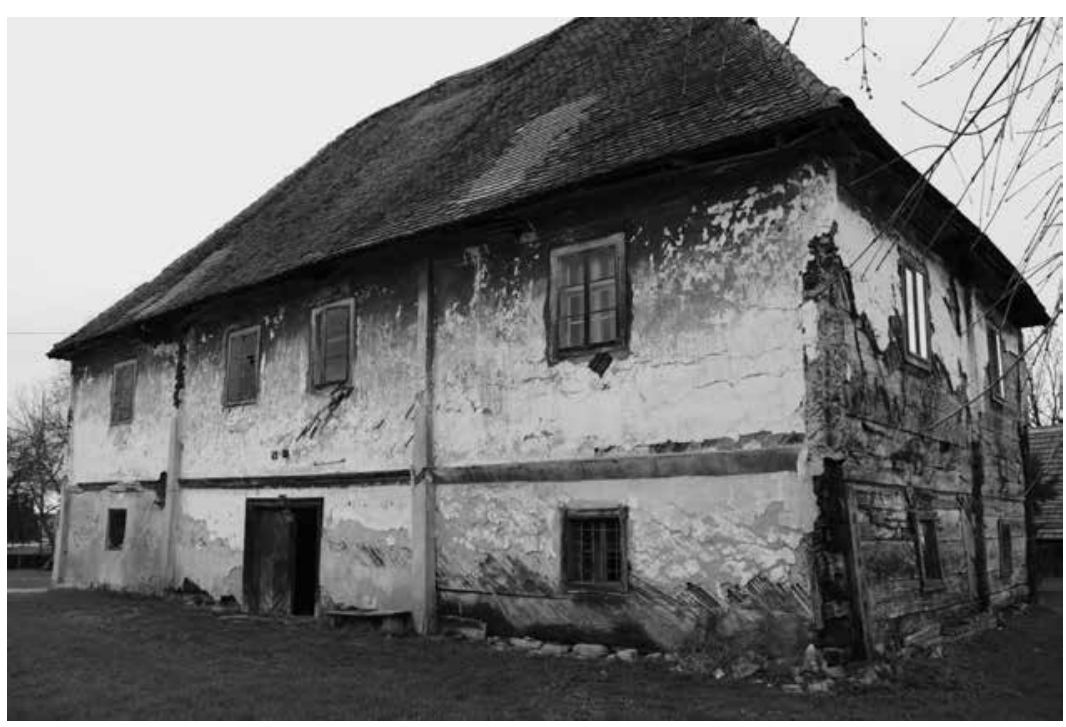

1. Vukovina, drveni dvorac, današnje stanje (foto: B. Vučić Šneperger) / Vukovina, timber manor house today

povijesti Emilija Laszowskoga i suradnika (I. 1910., II. 1911., III. 1924.), ali ga nalazimo nakon Drugoga svjetskoga rata, prvo uz pregled umjetničke baštine Turopolja Anđele Horvat (1961.), u potpisu pod reprodukcijama totala dvorca u Vukovini i detalja ulaznih vrata: »Drvena kurija Gašpara Alapića u Vukovini; Detalj vrata kurije Alapić u Vukovini. ${ }^{7}$ U istom desetljeću Višnja Huzjak piše: »Danas je najstarija sačuvana kurija $u$

posjetitelja čak i sada - u zapuštenom stanju - a pogotovo ako se u obzir uzme karakter konstrukcije i drveni materijal. Na drvenim vratima kata, kao i na ulaznima u dvorac očuvana je izvorna bravarija s rocaille-motivima, no namještaj iz 18. stoljeća nije očuvan, tek nekoliko predmeta potonjih vlasnika iz 19. i 20. stoljeća.

Vukovinsko vlastelinstvo privuklo je nešto više pozornosti od drvenoga dvorca, ali onu povjesničara. Spomen o njemu nalazimo u okviru istraživanja plemićkih obitelji, pa tako i Alapy, ili pak uprave vlastelinstvom njezinih nasljednika i korisnika, pogotovo redovnica klarisa iz samostana u Zagrebu. ${ }^{3}$ Jedino istraživanje koje je do sada bilo usmjereno na dvorac provela je s etnološko-konzervatorskog motrišta Ksenija Marković i objavila ga (1997.) u članku Dvor Alapić u Vukovini u obnovi 1997. ${ }^{4}$ U njemu je - između ostaloga izložila povijest vlasništva u 20. stoljeću te probleme pravne zaštite dvorca od 1964. godine kada je upisan u Registar nepokretnih spomenika kulture. Navela je i postupke koji su provedeni u cilju njegove zaštite. ${ }^{5}$ Ksenija Marković uključila je drveni dvorac u Vukovini u doktorsku disertaciju Drveni dvori središnje Hrvatske (2004.), ${ }^{6}$ ostavljajući ipak neodgovorenim mnoga pitanja. Ovom radu namjera je upozoriti na vlasnike tijekom 19. stoljeća, ponajprije na jednoga od njih koji je ostavio trag na današnjem izgledu dvorca, a do sada je bio nepoznat.

Među brojnim otvorenim pitanjima je i ono zašto se drveni dvorac zove "Alapić«, premda je ta obitelj izumrla krajem 16. stoljeća a ta oznaka dvorca ne javlja se u arhivskim dokumentima 17.i 18. stoljeća, kao ni u birokratskom rječniku katastra iz 19. stoljeća. Na popularnost hrvatskoga bana i vojskovođe Gašpara Alapyja i njegova vlastelinstva u Vukovini zacijelo je utjecao August Šenoa jer se u romanima Zlatarovo zlato (1871.) i Seljačka buna (1878.) pripovjedne zgode često zbivaju, započinju ili okončavaju u domu »hitroga grbuljka«, »Gašpara Alapića vukovinskoga«. Naziv »kurja Alapić« ne javlja se u slavnom pregledu turopoljske ovom kraju Alapićev dvor u Vukovini, građen sredinom 18. st. $\varkappa^{8}$ Čini se da je s vremenom Šenoin utjecaj prešao granice književnosti. Vukovinsko vlastelinstvo plemićke obitelji Alapy (Alapić, Alaphy, Allaphy, de Alap) nije im bilo u glavnom pridjevku, zvali su se prema drugom vlastelinstvu Velikokalnički. Tako su bili prihvaćeni u Plemenitu općinu Turopolje (22. studenoga 1569.), no nakon nepunih mjesec dana (21. prosinca 1569.) turopoljski župan izbacio je tri rođena brata "Gasparis, Stephani et Nicolai Alapy de Nagy Kemlek « iz turopoljskoga bratimstva. ${ }^{9}$ Uzrok poništenja bila je uzurpacija zajedničkih šuma Plemenite općine Turopolje za ispašu krda svinja koje su Alapići držali na svom posjedu - doslovce »u svom dvorcu « u Vukovini (»in castello eorum Wokowyna « $)^{10}$ - u Zagrebačkoj županiji. Vlastelinstvo Vukovina, osim mjesta po kome je dobilo ime, obuhvaćalo je i sela Okuje, Kupčina i Mičevec ${ }^{11}$ te nije bilo dio Plemenite općine Turopolje nego Zagrebačke županije.

Povijesni odnosi vlasništva vukovinskoga vlastelinstva i korisnika imanja jesu složeni, a jedini vlasnik koji se upisao slovima »P K ( (sl. 2) na današnjem dvorcu, nije bio poznat. Slova su plitko izrezbarena unutar srcolikoga obrisa s dvije biljne grane (lovora ?) pod njim, u drvenom »Zaglavnom kamenu « ulaznih vrata, odnosno na naknadno pribijenom izrezbarenom dekorativnom središtu nadvratnika. Za razrješenje inicijala Ksenija Marković (2004.) prenosi: "navodno inicijali tesara Pospišl Karla koji je, početkom stoljeća obnavljao ulazna vrata«. ${ }^{12}$ Premda je lako odbaciti takvu pretpostavku, jer je u ikonografiji portala to mjesto rezervirano za vlasnika (grb, natpis, godinu) a ne tesara koji obnavlja, za razrješenje inicijala potrebno je ukratko "prelistati posjedovne listove« vukovinskoga vlastelinstva kroz dva stoljeća. Izraz je, dakako, metaforičan, jer su tijekom toga razdoblja podaci o vlasnicima sačuvani neizravno kroz različite izvore.

Josip Adamček (1980.) piše o prvom vlasničkom prijenosu nakon nepunoga stoljeća kako su Alapići kupili 


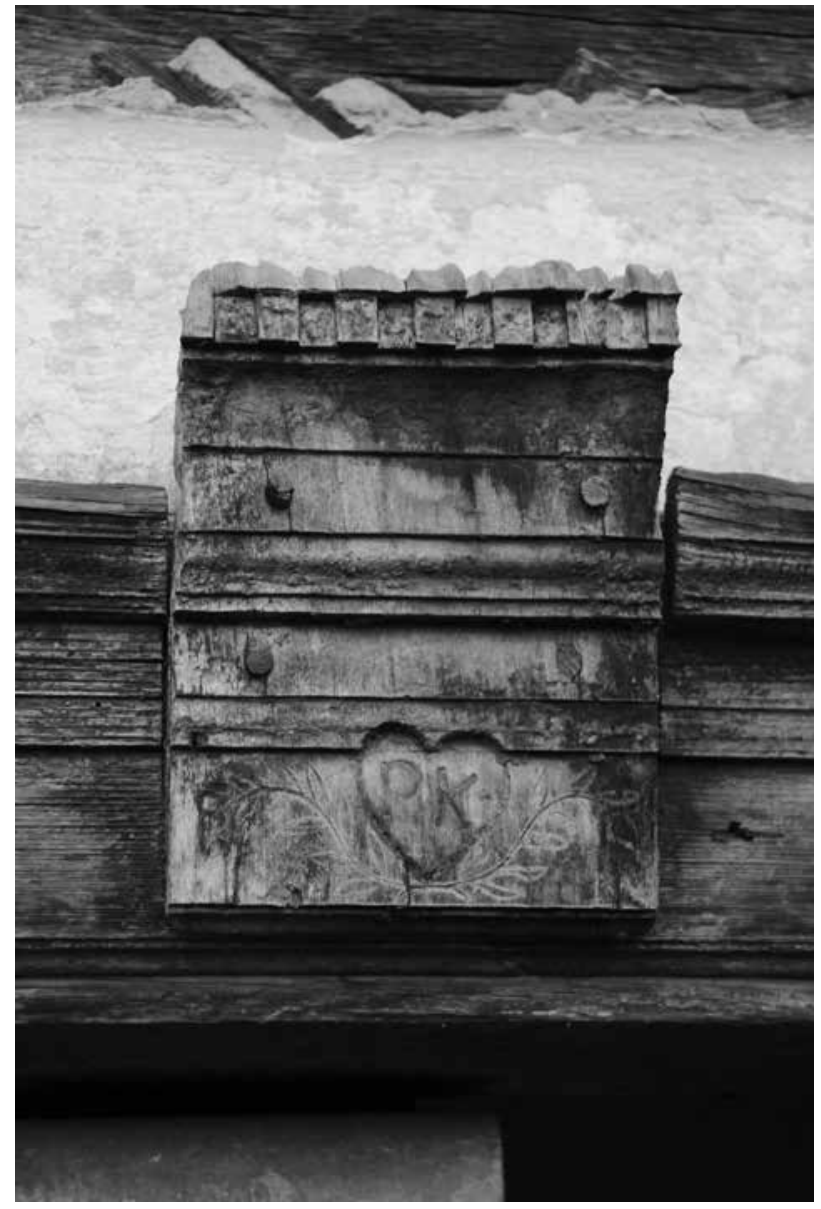

2. Vukovina, drveni dvorac, slova »P K « urezana na portalu (foto: B. Vučić Šneperger) / Vukovina, timber manor house, the letters " $P$ K" engraved on its portal

vukovinsko vlastelinstvo od Ivaniša Korvina (1496.), ${ }^{13}$ a koji je zanimljiv jer nije bio uobičajen, iako ne posve izniman: "God. 1585. umro je Nikola Alapy, posljednji muški član obitelji koja je držala vlastelinstva Veliki Kalnik i Vukovinu, te posjede Gregurovec i Kupčinu. Iako pitanje nasljeđivanja po ženskoj liniji nije bilo jasno fiksirano, te su posjede odmah zauzeli ženski članovi obitelji - Barbara Alapy - udovica Petra Erdödya, Marija Alapy - supruga Petra Draškovića, i Margareta Alapy - supruga Franje Orehoczyja. Parnica zbog naslijeđa obitelji Alapić (»causa Alapyana«) okončana je tek početkom XVII stoljeća, kad je i de jure priznato nasljeđe ženske loze. «1 ${ }^{14}$

Mladen Švab (1983.) navodi da je vukovinsko vlastelinstvo 1608. godine pripalo Marijani (Marija Ana) i Petru Draškoviću, ${ }^{15}$ no različiti arhivski dokumenti u Hrvatskom državnom arhivu upozoravaju na to da su sve tri obitelji u koje su se udale sestre Barbara, Marija Ana i Margareta iz obitelji Alapy, dakle Erdödy, Drašković i Orehoczy, i dalje prisutne na vukovinskom vlastelinstvu, premda posjed najvećim dijelom »uživaju«, to jest prihode s njega ubiru redovnice klarise i njime održavaju samostan i svoju zajednicu, kako pišu Laszowski i Barlè (1911.): »Za cijele se već prije dolaska klarisa u Hrvatsku radilo na njihovu naseljenju, jer već god. 1634. piše kardinal Petar Pazman grofu Gašparu Draškoviću, da svoje imanje u Vukovini predade klarisama: >titulo fundationis ‘. Do te predaje došlo je tekar god. 1645., kad je grof Gašpar Drašković izjavio pred zagrebačkim kaptolom, da svoja dobra u Vukovini predaje klarisama uza stalne pogodbe. Čim bi naime red klarisa u Hrvatskoj prestao, imaju ta dobra pripisati opet porodici Draškovićevoj.« ${ }^{16}$

U latinski naslovljenom, ali hrvatski (kajkavski) pisanom Urbarium et conscriptio bonorum omnium sororum Ordinis Sancte Matris Clare Conuentus iz 1656. godine, u Fondu samostana klarisa u Zagrebu naznačeno je i dalje suvlasništvo drugih obitelji, ${ }^{17}$ a u dokumentu koji slijedi, a nije datiran, no olovkom je poslije napisana ista 1656. godina - Urbarium Imania Wkouinskoga preko Szaue čitamo: »Na tom vukouinskome imaniu iese iedan duor, marof $\mathrm{i}$ zamaly visse od szto rali portinis Draskouichiane, ktero imanié, ut infra videre est, od Presuetloga ÿ Milostiunoga goszpodina Groffa Draskouich Gasparæ Gospam opaticzam daroiese. (...) Drugi Duor imaiu Gospe Opaticze od Familiæ Orechoczianæ, po imenom od odueeka Orechocÿ Petra. ${ }^{18}$

Opis zemljišnih posjeda naslovljen je »Terra curiales in Castello Wukovina «. ${ }^{19}$ Kada navodi dio zemljišta koji se obrađuje kao vrt, Urbarium razlikuje "portionis Erdeodianæ«, "portionis Orechoczianæ« $\mathrm{i}$ "portionis Draskouichianæ«. ${ }^{20}$ Laszowski i Barlè (1911.) naglašavaju da su Orehoczy nakon više od dva desetljeća od toga urbara izgubili svoj dio: »Tekar godine 1680. došlo je izmedju zagrebackkih klarisa i Petra Orahoczya [sic] do prijateljske nagodbe. Odvjetnik klarisa se obvezao, da će one platiti zagrebačkom kaptolu svotu od 1000 for., što ju je dugovao Petar Orahoczy no bez kamata. S protivne strane opet odrekao se je Petar Orahoczy u ime svoje te u ime svoje kćerke Marte i zeta Marije Bučića svih prava na Vukovinu. Podjedno je odstupio klarisama svoju očinsku kuriju u Vukovini sa svim pravima i koristima (...). $\ll^{21}$

Još u vrijeme kada je vlastelinstvo bilo izvor prihoda za zagrebačke klarise, u drugoj polovini 18. stoljeća, u posjed su ušle i druge obitelji koje su u Turopolju već imale posjede: "God. 1772. zatražile su klarise od Antuna p. Pucza i njegove supruge Terezije Modić, da vrate dva oteta vola njihovu podaniku Lovri Mikulanu. (...) Da su imali Modići takodjer neko pravo na Vukovinu, vidi se po tom, što su god. 1777. opomenuli klarise, neka nipošto ne kušaju porušiti staru kuriju u Vukovini. ${ }^{22}$

Iz arhivskoga fonda Zemljorasteretnoga ravnateljstva u Hrvatskom državnom arhivu u Zagrebu, iz serije Operati za urbarijalnu odštetu za godine 1854. i 1855., Štefanija Popović (1995.) zabilježila je u Vukovini dva vlasnika nakon ukidanja feudalnih odnosa (1848.): »271. VUKOVINA / Barbara Blažeković 13,2/8 selišta; 18 selišnih obitelji; 272. 


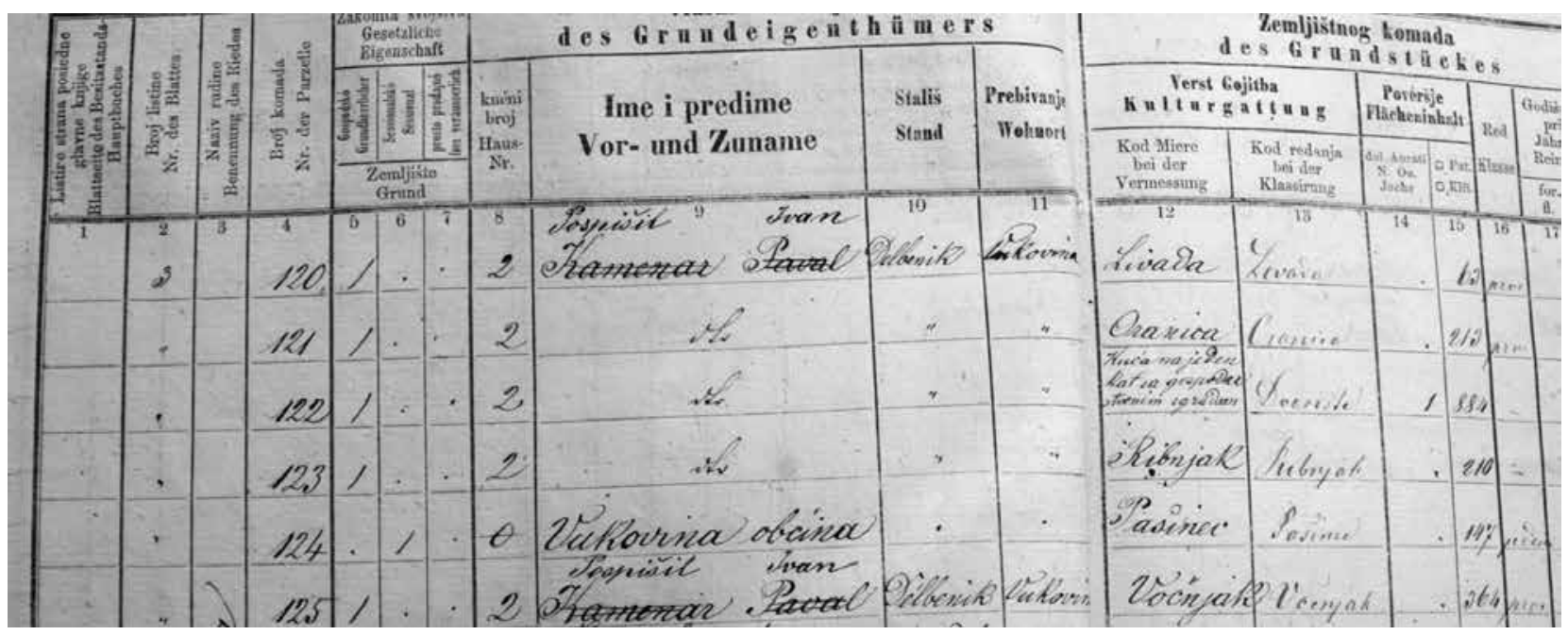

3. HDA, katastarski popis 1861., katastarska čestica 122 s dvorcem i prekriženom oznakom vlasnika »Kamenar Paval« (foto: S. Cvetnić) / HDA, 1861 land registry survey, lot 122, manor and the name "Kamenar Paval", which is crossed out

VUKOVINA / Vjerozakonska zaklada / 82,13/24 selišta; 74 selišne obitelji ${ }^{23} \mathrm{U}$ Vjerozakonsku zakladu prešao je onaj dio koji je imao ukinuti samostan zagrebačkih klarisa (1782.), a dio koji se vodi kao vlasništvo Barbare Blažeković vezan je vjerojatno uz onaj isti dio vlastelinstva koji je bio predmet spora obitelj Modić i Pucz (Pütz ?) s klarisama u posljednjoj četvrtini 18. stoljeća. Preko Barbare Blažeković, rođene Pütz, točnije njezine unuke Hanrijete ili Henrike Praunsperger, ${ }^{24}$ dolazimo i do prijedloga razrješenja zagonetnih urezbarenih vlasničkih slova $» \mathrm{P} \mathrm{K} «$. Henrijetin suprug zvao se Pavao Kamenar. To nisu jedini argumenti u prilog ovoga vlasnika. Naime, u katastarskom popisu, točnije Zapisniku Dielčićah Obćine Vukovina iz 1861. godine u Hrvatskom državnom arhivu, na mjestu današnjega dvorca nalazimo parcelu broj $122 \mathrm{~s}$ opisom: »Kuća na jedan kat s gospodarstvenim zgradam [sic]« i upisanim vlasnikom: »Kamenar Paval [prekriženo] Pospišil Ivan [dopisano iznad] « (sl. 3). Promjena vlasništva zbila se vjerojatno u vrijeme katastarskoga popisa, dakle neposredno nakon ili upravo 1861. godine. Na katastarskoj karti ucrtan je drveni dvorac (sl. 4) tlocrtnoga obrisa u obliku slova $» L$ « s prigradnjom na jugu koja više ne postoji. ${ }^{25}$ Prigradnja je smještena na parceli broj $125 \mathrm{~s}$ istim oznakama vlasnikā kao na parceli 122. Pavao Kamenar, a potom Ivan Pospišil, bili su vlasnici još jedne kuće, u blizini crkve, na parceli broj 10, određenoj kao »Gostiona sa ostarijom «. Daljnje svjedočanstvo o Pavlu Kamenaru kao vlasniku dijela vukovinskog vlastelinstva nalazimo na neočekivanu mjestu. U Knjižnici Hrvatske akademije znanosti i umjetnosti pohranjeno je šest knjiga iz 16. i prve polovine 17. stoljeća s vlasničkim naljepnicama na kojima piše: »Iz Knjižnice PAVLA KAMENARA Vukovinskog." Najstarija knjiga djelo je Apiana iz Aleksandrije - Rimski gradanski ratovi - izdana u Mainzu 1529. godine (sl. 5). ${ }^{26}$ Pavao Kamenar javlja se kao autor nekoliko hrvatskih govora još 1840. godine: u tiskari Ljudevita Gaja izdane su Kamenarove čestitke Josipu Šufflayu na imendan 19. ožuj-
4. HDA, katastarska karta 1861., katastarska čestica 122 s dvorcem i prigradnjom na katastarskoj čestici 125 (foto: S. Cvetnić) / HDA, 1861 land registry plan, lot 122, marking the manor and a new structure on lot 125

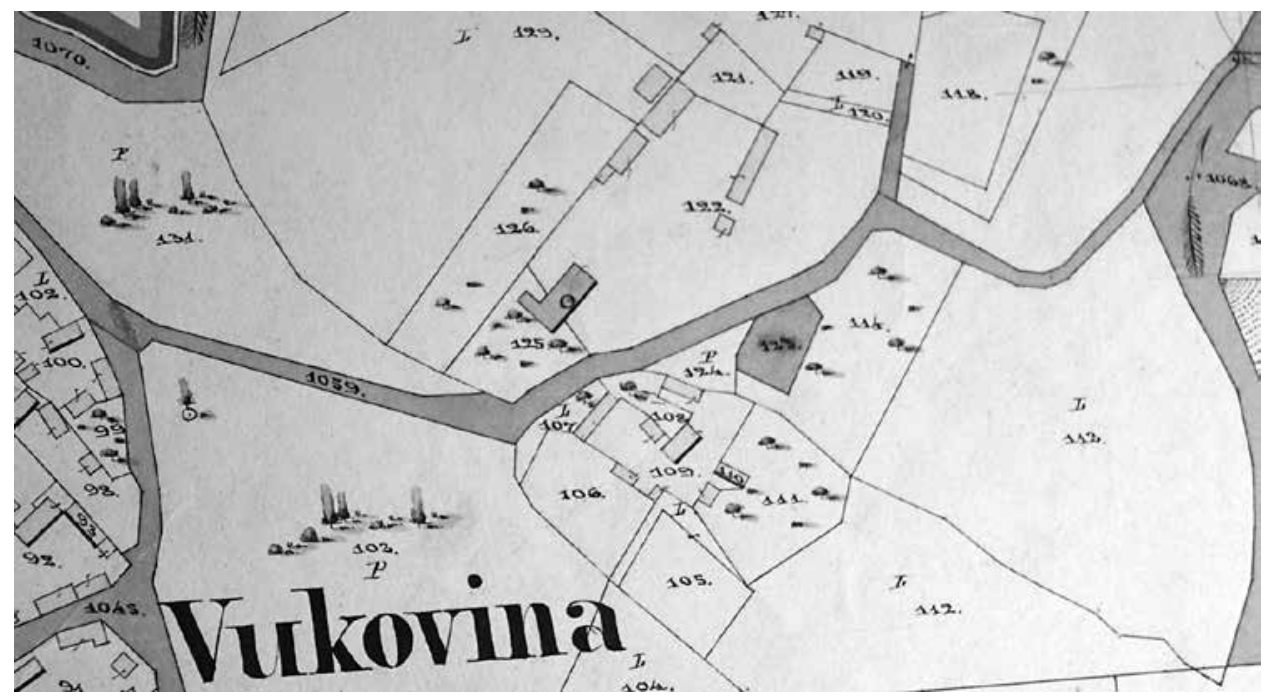




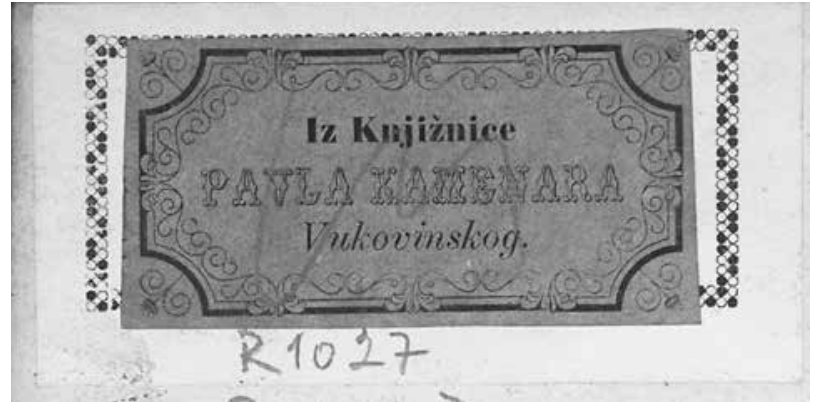

5. Knjižnica HAZU, naljepnica (ex libris): »Iz knjižnice PAVLA KAMENARA Vukovinskog.« na knjizi Apiana iz Aleksandrije De civilibus Romanorum bellis historiarum, Mainz / Moguntiae, 1529. (foto: T. Runjak) / HAZU library, ex libris sticker with the inscription "From the library of PAVAO KAMENAR Vukovinski", on the volume De civilibus Romanorum bellis historiarum (Mainz I Moguntiae 1529) by Apian of Alexandria

ka 1840., ${ }^{27}$ biskupu Jurju Hauliku u povodu predsjedanja saborom u proljeće 1840., ${ }^{28}$ oprosno pismo od Pavla Štoosa na njegovu odlasku sa službe profesora na mjesto župnika u Pokupskom (1842.). ${ }^{29}$ Objavljivao je i poslije (1854.; 1863.), no nije ušao u Hrvatski biografski leksikon. ${ }^{30}$ Emilij Laszowski o Pavlu Kamenaru piše samo na jednom mjestu, kada opisuje strast župnika Nikole Folnegovića prema knjigama: »U Starim Čičama našao je lijepu knjižnicu, a i sam imao je mnogo knjiga. Uz to je kupio na dražbi knjižnicu svog susjeda vlastelina, odvjetnika i latinsko-hrvatskog pjesnika Pavla Kamenara. Taj Kamenar bio je pravi čudak. Sio je na gotov imutak, vrijedan koju stotinu hiljada. Nije imao potomstva, nije pio, ni kartao ni gostio, a uza sve to umro je gotov prosjak. Došavši na Vukovinu, počeo je kraj dvora uz Odru zidati ogromnu zgradu - imao je biti mlin - ali ta zgrada nije bila nikada dovršena. Nakon dvadeset godina opet su ju porušili i opeku prodali za gradnju župnog dvora u Velikoj Gorici. Iz svoje knjižnice ponudio je župnik Folnegović jugoslavenskoj akademiji na dar sve, što si želi izabrati. Akademija je poslala u Staro Čiče Frana Kurelca, neka bira i donese što je za nju. «1

Vijest o Pavlu Kamenaru s ispravkom podatka o potomstvu nalazimo u komentaru objavljena rukopisa Narodne pjesme, pripoviedke, poslovice i zagonetke. Kupio ih oko Vrhovca u Hrvatskoj Gjuro Kamenar. 1878. Sanje Benković-Marković (2013.): »Betika (Barbara) bila je kći Pavla (najstarije dijete Pavla i Marije, rođ. Lukšić, brat Jurja Kamenara) i Henriete, rođ. Praunsperger (koja je naslijedila veliki imetak u Vukovini od svoje bake Blažeković, koji je Pavao uludo potrošio). Henrieta je dosta rano umrla te se stric Juraj brinuo o Betiki..132

Za neobičnu i razgranatu obitelj Kamenarā veže se i običaj vođenja obiteljske spomenice koju zovu Knjiga Alapića, koju je započeo spomenuti Pavlov mlađi brat Juraj u Vrhovcu kraj Ozlja: »Zanimljivost predstavlja Alapićeva knjiga. Kamenar je u Vrhovcu bilježnicu (bez crta s tvrdim koricama) uveo kao Knjigu Alapića i na prvoj stranici Juraj Kamenar vlastoručno piše: >(...) Ime mi je Kamenar Juro / srce moje nikad nije škuro / Radujem se svakog milog gosta / Jer imadem za njeg vina dosta / Izpit ću dobrodošlicu koja nije težka / Jer je radjena iz srebra i vreška / Nazivljem je čašu Alapića / Koj ju ne izpije vredan je biča.« «33

Na trećoj stranici rukopisne Knjige Alapića nalazi se prvi nadnevak, 24. travnja 1868., dakle knjiga je tako imenovana nakon što je Jurjev stariji brat Pavao Kamenar izgubio ili zbog dugova morao prodati Ivanu Pospišilu imanje u Vukovini, dio povijesnoga vlastelinstva. U obiteljskom govoru Kamenarā »Alapić« je postao nazdravičarska čaša ili pehar, kako objašnjava Sanja Benković-Marković: »Alapićje čaša s podnoškom ili pehar iz kojeg se pilo vino te nazdravljalo«, ${ }^{34}$ poput povika hrvatskoga plemstva Gaši Alapiću u Šenoinu romanu Zlatarovo zlato: „Vivat, Alapić, vivat!«

\section{BILJEŠKE}

1 Izraze dvorac i dvor (lat. curia) ili kurija nalazimo u literaturi razlikovane prema dimenzijama (dvorac je veći, kurija manja), materijalu (dvorac je zidani, kurija drvena) i/ili namjeni (dvorac je stan višega plemstva, kurija nižega plemstva i svećenstva). Razlikovanje nije provedeno sustavno, pa je izraz dvorac ovdje preuzet jer određuje tip građevine i ima povijesnoumjetničku tradiciju. Usp. VLADIMIR MARKOVIĆ, Jednokrilni drveni dvorci, Barokni dvorci Hrvatskog zagorja, Kajkavsko spravišče, Zagreb, 1975. [II. izd., 1995.], 77-80.

2 ANĐELA HORVAT, RADMILA MATEJČIĆ, KRUNO PRIJATELJ, Barok u Hrvatskoj, Liber, Zagreb, 1982., 76.

3 Usp. IVAN KUKULJEVIĆ SAKCINSKI, Veliki Kalnik, IVAN STANDL, Fotografijske slike iz Dalmacije, Hrvatske i Slavonije [optički disk], Zagreb : Hrvatski državni arhiv, s. a. 1870. [2009.], s. p.; EMILIJ LASZOWSKI uz suradništvo JANKA BARLĖA, Povijest plem. općine Turopolja nekoć Zagrebačko polje zvane. Općinske uredbe, povijest crkvi i odnosi nekih crkvenih redova prema općini turopoljskoj, sv. II, Zagreb : tiskom Antuna Scholza, 1911. [1996.], 406, 412-419; JOSIP ADAMČEK, Agrarni odnosi u Hrvatskoj od sredine XV do kraja XVII stoljeća, Jugoslavenska akademija znanosti i umjetnosti; Sveučilište u Zagrebu, Centar za povijesne znanosti, Odjel za hrvatsku povijest; Sveučilišna naklada Liber, Zagreb, 1980.

4 KSENIJA MARKOVIĆ, Dvor Alapić u Vukovini u obnovi 1997., Radovi Hrvatskog društva folklorista, 5-6 (1997.), 267-279. Na podršci u istraživanju zahvaljujem suvlasniku dvorca, akademskom kiparu Mladenu Mikulinu.

5 KSENIJA MARKOVIĆ (bilj. 4), 268. Od tada je dvorac unesen na Listu zaštićenih kulturnih dobara Registra kulturnih dobara Republike Hrvatske (2009.) pod brojem Z-4246. Usp. Izvod iz Registra kulturnih dobara Republike Hrvatske br. 04/09, Narodne novine. Službeni list Republike Hrvatske, 17 (2010.), 408.

6 KSENIJA MARKOVIĆ, Drveni dvori središnje Hrvatske, doktorska disertacija, Filozofski fakultet, Zagreb, 2004., 7-8, 11, 145-148, 398-415. 7 ANĐELA HORVAT, Prilog poznavanju spomenika NO općine Velika Gorica (Turopolje), Vijesti muzealaca i konzervatora Hrvatske (Spomenici kulture Turopolja), X/5 (1961.), 144-145.

8 VIŠNJA HUZJAK, Drveno graditeljstvo Turopolja, Muzej Turopolja, Velika Gorica, s. a. [1969.], s. p. [4].

9 Usp. EMILIJ LASZOWSKI, Povijesni spomenici Plemenite općine Turopolja nekoć "Zagrebačko polje« zvane. IV, 1560-1895. Zagreb : tiskom Antuna Scholza, 1908., 17-18 (isprava br. 11). 
10 Ibid.

11 Usp. EMILIJ LASZOWSKI uz suradništvo JANKA BARLÈA (bilj. 3), 414

12 KSENIJA MARKOVIĆ (bilj. 6), 146.

13 »Već u januaru 1593. upadnu Turci opet u Turopolje. Oplijene i spale kaštel u Vukovini, a skoro su i grad Želin zauzeli. Mjeseca februara eto ih opet do sela Vukovine, gdje ih ban Toma Erdödy opet potisne.« EMILIJ LASZOWSKI uz suradništvo VELIMIRA DEŽELIĆA i MILANA ŠENOE, Plemenita općina Turopolje: zemljopis, narodopis i povjesni prijegled, sv. I, Zagreb : tiskom Antuna Scholza, 1910., 276. Utvrda u mjestu Wukowina ucrtana je na karti Croatia \& Sclavonia u Glavnom zemaljskom arhivu (Generallandesarchiv, Bd. XV) u Karlsruheu, na istoimenoj karti u Zbirci rukopisa, spisa i ostavštine Austrijske nacionalne knjižnice u Beču (Handschriften-, Autographen- und Nachlass-Sammlung der Österreichischen Nationalbibliothek Wien, Cod. 8609, fol. 2v-2) te u potpisanoj karti Vngariae loca precipva descripa per Nicolav Angielv Italv u Saskome državnom arhivu u Dresdenu (Sächsisches Hauptstaatsarchiv, Schr. XXVI, F. 96, Nr. 6). Usp. IVKA KLJAJIĆ, Kartografski prikazi hrvatskih gradova iz 16. stoljeća, doktorska disertacija, Geodetski fakultet, Zagreb, 2006., 257-258, 260.

14 JOSIP ADAMČEK (bilj. 3), 432. Hrvatski državni arhiv (dalje: HDA), Neoregestrata acta NRA, 641/19, 592/4, 592/5, 592/21, 400/38, $61 / 3,410 / 20,641 / 22$.

15 Usp. MLADEN ŠVAB, "Alapić (Alaphy, Alapy, Allaphy)«, Hrvatski biografski leksikon, sv. I (A-Bi), (ur.) Nikica Kolumbić, Leksikografski zavod »Miroslav Krleža«, Zagreb, 1983., 50.

16 EMILIJ LASZOWSKI uz suradništvo JANKA BARLÈA (bilj. 3), 413-414.

17 HDA, fond 672 Samostan klarisa u Zagrebu, fasc. I., br. 3, s.f.

18 HDA, fond 672 Samostan klarisa u Zagrebu, fasc. I., br. 3, fol. 12v (cjelokupni sveščić fol. 12v-20r, dalje popis kmetova).

19 HDA, fond 672 Samostan klarisa u Zagrebu, fasc. I., br. 3, fol. 12r. 20 »Item vert polagh Duora [nečitka riječ: tvoie?] Gospodé, portionis Orechoczianæ polagh grabe od melina: ù srede portio Draskouichianæ $\ddot{y}$ skraia portio Erdeodianæ. Na Szaue iessu chetueri melini na gospodske zemlie, iduchi na mlaku ueliku, od sakoga ide ieden Dukat opaticzam na let.« HDA, fond 672 Samostan klarisa u Zagrebu, fasc. I., br. 3, fol. 12r.

21 EMILIJ LASZOWSKI uz suradništvo JANKA BARLÈA (bilj. 3), 417. 22 Ibid.

23 ŠTEFANIJA POPOVIĆ, Popis imanja Zagrebačke županije $u$ doba ukidanja feudalnih odnosa, Radovi Zavoda za hrvatsku povijest, 28 (1995.), 291.

24 »Ivan Blažeković se u izvorima iz 1803. javlja kao satnik 53. regimente, a poslije kao major. Vukovinsko vlastelinstvo mu je u miraz donijela njegova supruga Barbara (Babette), rođena Pütz. Njihova djeca bila su Franciska i Juraj. Franciska se udala za Antuna (Danijela ?) Praunšpergera. Njihova kći zvala se Henrijeta (Henrika), udana za Pavla Kamenara.«; Državni arhiv u Zagrebu, fond 818 Obitelj Blažeković. Iz opisa fonda.

25 Zbog žbukanoga pročelja, dvorac je označen ružičasto, premda je drven.

26 [APIAN IZ ALEKSANDRIJE], Appiani Alexandrini De civilibus Romanorum bellis historiarum, Mogvntiae, In Ædibus I. Schoeffer, 1529. Sign. R-1027. Prema katalogu, oznake vlasništva Pavla Kamenara Vukovinskoga nose knjige objavljene u Mainzu (1), Antwerpenu (1), Lyonu (1) i Leidenu (3). Manji posjednik i vlasnik podijeljenih katastarskih čestica, što je označeno u Zapisniku Dielčićah Obćine Vukovina: „Stališ: Delbenik«, Pavao Kamenar ponosno si je pridao naziv čitava vlastelinstva, Vukovinski. Na pomoći u ovom dijelu istraživanja naljepše zahvaljujem upraviteljici Knjižnice Hrvatske akademije znanosti i umjetnosti mr. sc. Vedrani Juričić, voditeljici zbirke rijetkosti Tamari Runjak, voditeljici knjižnice Strossmayerove galerije starih majstora Ini Šamac Flaschar te Ivani Katušić.

27 [PAVAO KAMENAR], Pjesma na čast (...) gospodina Jos. Šuflaja, (...) na godovnomu svetkovanju 19. ožujka 1840. Čestituje Pavel Kamenar. U Zagrebu: tiskom k. p. nar. ilir. tiskarne dra. Ljudevita Gaja, 1840.

28 [PAVAO KAMENAR], Slava (...) Gjuri Hauliku, Božjom i apostolske stolice milostju biskupu zagrebačkomu (...) prigodom kada se je iz sabora obćinskoga natrag vratio u proljetje 1840., iz najdublje i snižene strahopočitnosti čestitana po Pavlu Kamenaru. U Zagrebu: tiskom k. p. ilir. nar. tiskarne dra. Ljudevita Gaja, 1840.

$29 »(.$.$) u ime cjelokupne akademičke mladeži najsrdačnije (se) oprostio$ Pavao Kamenar, slušatelj II. godine filozofije.« STJEPAN ORTNER, Život i rad Pavla Stoósa: hrvatskog pjesnika i svećenika, Šimunić i drug, Zagreb, 1907., XIII.

30 Usp. Hrvatski biografski leksikon, sv. VII (Kam - Ko), (ur.) Trpimir Macan, Leksikografski zavod »Miroslav Krleža«, Zagreb, 2009. Bez točnih anagrafskih podataka, možemo tek posredno zaključiti da je rođen oko 1820. godine (na drugoj godini studija bio je 1842.), možda u Ivanić-Gradu, kao dijete Pavla Kamenara i Marije, rođene Lukšić. Njegov mlađi brat Juraj Kamenar rođen je 1834. godine kao sedmo dijete u istoj obitelji.

31 EMILIJ LASZOWSKI uz suradništvo JANKA BARLĖA (bilj. 3), 296. 32 SANJA BENKOVIĆ-MARKOVIĆ, Đuro Kamenar zapisivač tradicijske grade, [GJURO KAMENAR], Narodne pjesme, pripoviedke, poslovice i zagonetke. Kupio ih oko Vrhovca u Hrvatskoj Gjuro Kamenar. 1878., Matica hrvatska, Zagreb, 2013., 439.

33 SANJA BENKOVIĆ-MARKOVIĆ (bilj. 32), 437. Prva dva djeteta Jurja Kamenara rođena su u Remetama, gdje su pokopani grbuljak Gašpar i njegov otac Ivan Alapić, suprug Margarete Zrinske (sestre Nikole Sigetskoga). SANJA BENKOVIĆ-MARKOVIĆ (bilj. 32), 432.

34 SANJA BENKOVIĆ-MARKOVIĆ (bilj. 32), 437. 
Summary

Sanja Cvetnić

Pavao Kamenar and the Timber Manor House in Vukovina

Of the few surviving timber manor houses in the Turopolje area one should single out the timber manor house in Vukovina, built in the 18th century. More timber manor houses were built in the 19th century, e.g. the Modić-Bedeković family manor in Donja Lomnica (1806) or the old parish house (curia) in Stari Čic (1831). Other manors, such as the one in Kurilovec, owned by the Jelačic family, fell into disrepair in the recent past. Among them only the Josipovic manor (also in Kurilovec) has been "preventively deconstructed". Today the timber manor in Vukovina mostly goes by the name of the "Alapic curia", although the Alapy family died out at the end of the 16th century (1585), and the manor passed along the female line to the great noble families Drašković, Orehoczy and Erdödy. After 1645 the income of the manor went to the nuns of Saint Claire's order in Zagreb. Recently found materials have thrown some light on the decade preceding the land registry survey of 1861, drawing our attention to Pavao Kamenar, who at that time was the owner of the timber manor, and whose initials are still discernible on the manor's portal. The books of Kamenar's library were provided with ex libris stickers bearing the inscription "From the library of PAVAO KAMENAR". This article offers a short overview of the literature and archive data mentioning the inheritors of the Vukovina estate after its division at the beginning of the 17th century, and their decision in the mid-17th century to donate the earnings of the estate to the Clarist monastery in Zagreb.

The literature and archive materials also note the changes of owners through the 18th century. However, during these two centuries and the 19th century the name "Alapic curia" is not mentioned in the documents, nor does the name appear in the History of Turopolje by Emilij Laszowski published at the beginning of the 20th century.

The present custom of referring to the manor as "the Alapic curia" obviously resulted from the popularity of the Croatian Viceroy and military leader Gaspar Alapy, who owned the Vukovina estate in the 16th century, and became a legendary fictional hero in the novels of the popular and widely read Croatian novelist August Šnoa in the 19th century. In his novels The Goldsmith's Daughter (1871) and The Peasants' Uprising (1878) Šnoa sets many fictional scenes in the home of "Gašpar Alapić of Vukovina". 